\title{
Effect of cord clamping time on neonatal vitamin B12, folate and urinary iodine concentration
}

\author{
Özgül Özgan Çelikel ${ }^{1}$, Nilgün Altuntaş² ${ }^{2}$, Nurkan Aksoy ${ }^{2}$ (D) \\ 'Lokman Hekim Univercity, Bağlıca mah. Bağlıca Bulvarı Eskiçayır Cad. Afşaroğlu Konakları, Ankara, Turkey \\ ${ }^{2}$ Ankara Yıldırım Beyazıt University Faculty of Medicine, Turkey
}

\begin{abstract}
Objectives: The aim of this randomised study was to investigate whether early or late clamping of the cord influences the status of micro-elements and thyroid hormone levels in newborns.

Material and methods: The study participants were randomised into two groups: Group 1, in which cord clamping was performed within $10 \mathrm{~s}(\mathrm{n}=32)$ and Group 2, in which clamping was performed at the $60^{\text {th }}$ second $(\mathrm{n}=28)$. Sociodemographic parameters were recorded; maternal and neonatal levels of free triiodothyronine (FT3), free thyroxine (FT4), thyroid stimulant hormone (TSH), urinary iodine concentration levels (UIC) folate and vitamin B12 were measured.

Results: Of the maternal and neonatal thyroid hormone values examined, a significant difference was determined between the groups only in respect of the FT4 and FT3 values of the newborns in the first 24 hours ( $p=0.037, p=0.009$, respectively). The FT4 values in the first 24 hours were determined to be lower than normal in $15.6 \%$ ( $n: 5)$ of the newborns in Group 1 and in $0 \%$ of Group 2. The FT3 values in the first 24 hours were determined to be lower than normal in $62.5 \%$ (n: 20) of the newborns in Group 1 and in 28.5\% of Group 2. Vitamin B12 values below the normal limit were determined at a significantly higher rate in Group $1(p=0.009)$. A statistically significant positive correlation was observed between the maternal and neonatal vitamin B12 levels $(r: 0.334, p=0.009)$.

Conclusions: Late clamping of the umbilical cord may contribute to erythrocyte synthesis by allowing passage of vitamins such as B12 and folic acid to the newborn.
\end{abstract}

Key words: cord clamping; vitamin B12; folate; urinary iodine concentration

\section{INTRODUCTION}

Fetal nutrients are received from the placenta and umbilical cord, and the timing of cord clamping may affect the newborn. There are reports suggesting that delayed cord clamping in healthy term infants increases early and late haemoglobin concentrations and iron reserves in infants [1]. The timing of the cord clamping is a subject of debate [2]. The World Health Organisation recommends delayed umbilical cord clamping at 1-3 minutes after birth [3]. Delaying the umbilical cord clamping by at least 30-60 seconds after birth is recommended by the International Liaison Committee on Resuscitation, and this has been included in several guidelines [4]. There are ongoing physiological-based cord clamping [5] studies that recommend cord clamping only after breathing has started $[6,7]$.

lodine is necessary for the production of thyroid hormones (thyroxine and tri-iodothyronine), which are of vital importance for the brain and neurological development of the fetus during pregnancy and in the early neonatal period [1]. Therefore, iodine deficiency (ID) is an important public health problem [5-7], as it not only affects fetal brain development, but severe maternal ID can cause an increase in neonatal deaths, recurrent miscarriages and preterm labor [8].

Vitamin B12 deficiency in pregnancy (< $148.0 \mathrm{pmol} / \mathrm{L})$ has been associated with spontaneous abortion, pregnancy loss, intrauterine growth retardation, low birth weight $(<2500 \mathrm{~g})$, and the risk of neural tube defects [9]. Inadequate vitamin B12 during pregnancy and early childhood may cause long-term adverse effects on the growth and development of children [10]. Folate is very important during pregnancy for embryological development because of its role in the synthesis of DNA and neurotransmitters, amino

\footnotetext{
Corresponding author:

Özgül Özgan Çelikel

Lokman Hekim Univercity, Bağlıca mah. Bağlıca Bulvarı Eskiçayır Cad. Afşaroğlu Konakları no: 3/11-A, 06790 Ankara, Turkey

e-mail:drozgulozgan@gmail.com
} 
acid metabolism, protein synthesis and cell proliferation. Folate deficiency increases the risk of pre-eclampsia and fetal anomaly [11]. In addition to the importance for normal neurodevelopment, it is also essential for mental and emotional health [2]. The clinical symptom of folate deficiency is megaloblastic anemia, and folate deficiency has been associated with an increased risk of cancer and neural tube defects [12].

Although there are reports that the timing of cord clamping affects haemoglobin and iron levels, it is not known whether the time of clamping has an effect on other micro-elements and thyroid hormones. To the best of our knowledge, this is the first study to have examined this subject.

The aim of this randomised study was to investigate whether early or late clamping of the cord has an effect on the status of micro-elements and thyroid hormone levels in newborns.

\section{MATERIAL AND METHODS}

The study was conducted between 15 February 2018 and 15 August 2018 in the delivery room and neonatal outpatient clinic of the Gynaecology and Obstetrics Department at a tertiary hospital. Approval for the study was obtained from the Local Ethics Committee (decision no: 01, dated: 2018). The study included women at 36-42 weeks of pregnancy who were admitted to our hospital for delivery. Patients were excluded from the study if they had a diagnosis of a chronic systemic disease, a diagnosis of endocrine or metabolic disease during pregnancy, chronic drug or multivitamin use, fetal anomalies or multiple pregnancy. Infants with suspected sepsis in the postnatal examinations and tests, those with anomalies, those identified with foetal distress or those who required postnatal resuscitation were not included in the study. Cord clamping was performed in the first 10 seconds after delivery in the early cord clamping group (Group 1) and at the $60^{\text {th }}$ second in the late cord clamping group (Group 2). Eight mothers and their infants were excluded from the study; two who required resuscitation, and six who could not be monitored. Thus, the early cord clamping group comprised 32 pairs of mothers and infants, and the late cord clamping group comprised 28 pairs of mothers and infants. All procedures applied to patients and newborns were in accordance with the 1964 Helsinki Declaration and its later amendments.

All the pregnant women included in the study were admitted for delivery, met the study inclusion criteria, and provided informed consent for participation in the study. No uterotonic drugs or oxytocin were used in any of the cases in the study before cord clamping. Blood samples were taken into $5 \mathrm{~mL}$ biochemistry tubes and $3 \mathrm{~mL}$ hemogram tubes before delivery. These samples were centrifuged at
$3000 \mathrm{rpm} / \mathrm{min}$ at $4^{\circ} \mathrm{C}$, then stored at $-80^{\circ} \mathrm{C}$ until assay. Spot urine samples of $5 \mathrm{~mL}$ obtained from all the pregnant women were stored at $-20^{\circ} \mathrm{C}$ until further tests. Blood samples were taken from the newborns at 24 hours after birth into $5 \mathrm{~mL}$ biochemistry tubes and $3 \mathrm{~mL}$ hemogram tubes, centrifuged at $3000 \mathrm{rpm} / \mathrm{min}$ at $4^{\circ} \mathrm{C}$, then stored at $-80^{\circ} \mathrm{C}$ until further tests. Before discharge, $5 \mathrm{cc}$ spot urine samples were taken from the infants within postnatal 72 hours and stored at $-20^{\circ} \mathrm{C}$ until assay. The infants included in the study were examined again on the $10^{\text {th }}$ postnatal day to determine the levels of free triiodothyronine (FT3), free thyroxine (FT4) and thyroid stimulating hormone (TSH). Blood samples were taken into $5 \mathrm{~mL}$ biochemistry tubes and centrifuged at $3000 \mathrm{rpm} / \mathrm{min}$ at $4^{\circ} \mathrm{C}$ and stored at $-80^{\circ} \mathrm{C}$.

Assay of the blood samples: All the blood samples obtained from mothers and infants at appropriate times according to the study protocol were thawed at room temperature to evaluate the levels of vitamin B12, folate, FT3, FT4 and TSH.

TSH (adult range: $0.27-4.2 \mathrm{mIU} / \mathrm{L}$; newborn range: 0.7-15.2 mIU/L), FT3 (adult range: 2.04-4.4 ng/L; newborn range: $1.73-6.3 \mathrm{ng} / \mathrm{L}$ ), FT4 (adult range: $0.85-1.7 \mathrm{ng} / \mathrm{dL}$; newborn range: $0.86-2.49 \mathrm{ng} / \mathrm{dL}$ ), folic acid (range: $4.6-18$, $7 \mathrm{ng} / \mathrm{mL}$ ) and vitamin B12 (range: 197-771 ng/L) levels were measured using the CLIA method (Siemens Advia Centaur XPT). The Hemoglobin ( $\mathrm{Hb}$ ) (range: $11-18 \mathrm{~g} / \mathrm{dL}$ ) level was measured spectrophotometrically.

Assaying of urine samples: The urine samples obtained from mothers and newborns stored at $-20^{\circ} \mathrm{C}$ were thawed at room temperature for assay. The iodine levels in urine were assayed with the colorimetric method using an Italian brand kit. The values were calculated by determining the absorbance at $405 \mathrm{~nm}$ and creating a graph using the calibrator values. The standard urine iodine range is $100-700 \mu \mathrm{g} / \mathrm{dL}$.

Compounds containing iodine, such as povidone iodine, were not used during the preoperative preparation to avoid changes occurring in the iodine levels of the mothers and newborns with the absorbance method. Similarly, agents containing iodine were not used in the abdomen care of the newborns for 10 days postoperatively.

The values obtained from the blood test results of the mothers and newborns were recorded in comparison with the standard values of the test kits as low if below the normal lower limit value, high if above the upper limit value, and normal if within the normal range. The values were then compared statistically between the groups.

Body mass index measurement: The demographic characteristics of the mother were recorded at the beginning of the study and those of the newborn were recorded after birth. The body mass index (BMI) of the mothers was calculated. Weight was recorded with the subject wearing only light clothing and no shoes, and height was measured with the subject in 
a standing position. Body mass index (BMI) was calculated by dividing body weight in kilograms by height in meters squared.

\section{Statistical analysis}

According to the $\mathrm{G}^{*}$ Power 3.1.9.2 (University of Dusseldorf, Germany) software calculation, from the analyses of 35 pregnant women with early cord clamping and 33 pregnant women with late cord clamping, the effect width was 0.475 minimum. The power of the study calculated over this effect width was found to be $97.75 \%$. The sample numbers included in the study were found to be sufficient.

Data obtained in the study were analysed statistically using IBM SPSS Statistics 23 software (IBM statistics for Windows version 23, IBM Corporation, Armonk, NY, USA). The assumptions of normality of numerical variables were examined using the Shapiro-Wilk normality test, and it was observed that certain variables were normally distributed, whereas others were not. Therefore, parametric and nonparametric statistical methods were used in the study. The relationships between two independent categorical variables were interpreted using Chi-square analysis. Fisher's exact test results were used in cases where the assumption of the expected value was not achieved with Chi-square analysis. Differences between two independent variables were examined using the Independent Samples $t$-test for variables showing normal distribution and the Mann-Whitney $U$-test for variables not showing normal distribution. Differences between two dependent numerical variables were examined using the Dependent Samples $t$-test for variables showing normal distribution and the Wilcoxon test for variables not showing normal distribution. The relationship between two independent numerical variables was interpreted using Spearman's rho correlation coefficient. A value of $p<0.05$ was considered statistically significant.

\section{RESULTS}

The demographic and clinical characteristics of the mothers and infants are summarised in Table 1. There was no statistically significant difference between the groups in terms of age, duration of education, monthly income, weight gain during pregnancy, BMI, gravida, parity, gestational week, delivery type and birth weight, infant gender, need for hospitalisation and mode of feeding ( $p>0.05$; Tab. 1).

When the blood sample results were classified according to the standard values of the test kit, the maternal TSH values were seen to be higher than normal in three patients in Group 1 and in four patients in Group $2(p=0.423)$. The TSH values of the newborns within the first 24 hours were observed to be higher than normal in 1 of Group 1 and in all of Group $2(p=0.533)$.

A statistically significant difference was determined between the groups in respect of maternal and neona- tal thyroid hormone values in the FT4 and FT3 values of the newborns in the first 24 hours ( $p=0.037, p=0.009$ ). The FT4 values in the first 24 hours were determined to be lower than normal in $15.6 \%$ ( $n: 5)$ of the Group 1 newborns and in $0 \%$ of Group 2. The FT3 values in the first 24 hours were determined to be lower than normal in $62.5 \%$ (n: 20$)$ of the Group 1 newborns and in $28.5 \%$ of Group 2 ( $p=0.009$ ). On the $10^{\text {th }}$ day, no statistically significant difference was observed between the groups in respect of the thyroid hormone levels of the newborns ( $p>0.005$ for all) (Tab. 2, Fig. 1).

The neonatal vitamin and iodine values were evaluated according to the time of cord clamping. Comparisons were made by classification of these values according to the standard values of the test kits. No difference was determined between the groups in respect of maternal serum vitamin B12, folic acid and urinary iodine levels ( $p=0.098$, $p=0.567, p=0.379$, respectively), and a significant rate of cases in Group 1 were determined with B12 values below normal $(p=0.009)$. In both groups, there were no cases with neonatal folic acid values below normal. Folic acid values were determined to be above normal in $50 \%$ of Group 2, and in Group 1, this rate was significantly low ( $p=0.032$ ).

The maternal and neonatal vitamin B12 and iodine values are shown in Table 3 and Figure 2. A statistically significant positive relationship was determined between the maternal and neonatal vitamin B12 levels ( $\mathrm{r}: 0.334, \mathrm{p}=0.009$ ). No statistically significant relationship was determined between the maternal and neonatal folic acid levels ( $r: 0.134$, $p=0.307)$.

\section{DISCUSSION}

There has been a recent increase in publications on delayed clamping of the umbilical cord in healthy term infants, and these studies have suggested that delayed cord clamping particularly increases the early haemoglobin concentrations and iron reserves in infants [13]. It has been reported that clamping at 30 seconds after birth provided infants with better iron reserves and better cardiopulmonary adaptation [14].

Increased metabolic needs and hormonal changes during pregnancy lead to a significant increase in iodine requirements, which is due to a $50 \%$ increase in thyroid hormone production and a $30-50 \%$ increase in renal iodine excretion during early pregnancy [15].

In a study from a region of Turkey deficient in iodine, maternal and neonatal iodine levels were measured and it was reported that while there was ID in $56.8 \%$ of the mothers, the majority of the infants (61.0\%) were determined with excessive iodine and $10 \%$ with ID. However, it was stated that the use of iodine-containing agents during the birth could have caused the increase in iodine in the infants [16]. Therefore, in the current study, to ensure that thyroid hormone levels 


\begin{tabular}{|c|c|c|c|}
\hline & $\begin{array}{l}\text { Group } 1 \\
(n=32)\end{array}$ & $\begin{array}{l}\text { Group } 2 \\
(n=28)\end{array}$ & $\mathbf{P}$ \\
\hline $\begin{array}{l}\text { Age [year] } \\
\text { Mean. } \pm \text { SD }\end{array}$ & $30.81 \pm 4.07$ & $29.79 \pm 3.96$ & $0.327^{a}$ \\
\hline $\begin{array}{l}\text { Education [year] } \\
\text { Median (Min-Max) }\end{array}$ & $8(5-18)$ & $12(5-16)$ & $0.365^{b}$ \\
\hline $\begin{array}{l}\text { Montly income }[T L] \\
\text { Median (Min-Max) }\end{array}$ & $3750(2000-10000)$ & $5000(2000-11000)$ & $0.226^{b}$ \\
\hline $\begin{array}{l}\text { Weight gain in pregnancy }[\mathrm{kg}] \\
\text { Median (Min-Max) }\end{array}$ & $13(5-35)$ & $14.5(10-35)$ & $0.083^{b}$ \\
\hline $\begin{array}{l}\text { BMI }\left[\mathrm{kg} / \mathrm{m}^{2}\right] \\
\text { Median (Min-Max) }\end{array}$ & $1.85(18-22)$ & $19.16(16.54-22.2)$ & $0.259^{b}$ \\
\hline $\begin{array}{l}\text { Gravida } \\
\text { Median (Min-Max) }\end{array}$ & $2(1-6)$ & $2(1-5)$ & $0.556^{b}$ \\
\hline $\begin{array}{l}\text { Parity } \\
\text { Median (Min-Max) }\end{array}$ & $1(0-5)$ & $1(0-3)$ & $0.693^{b}$ \\
\hline $\begin{array}{l}\text { Gestational week } \\
\text { Median (Min-Max) }\end{array}$ & $38.75(34-41)$ & $39(36-41)$ & $0.466^{b}$ \\
\hline $\begin{array}{l}\text { Birth weight of newborn }[\mathrm{gr}] \\
\text { Mean } \pm \text { SD }\end{array}$ & $3225.63 \pm 424.52$ & $3312.5 \pm 302.31$ & $0.371^{a}$ \\
\hline $\begin{array}{l}\text { Vaginal birth } \\
\text { Number }(\%)\end{array}$ & $21(65.6)$ & $16(57.1)$ & $0.500^{*}$ \\
\hline $\begin{array}{l}\text { Cesarean section } \\
\text { Number }(\%)\end{array}$ & $11(34.4)$ & $12(42.9)$ & \\
\hline $\begin{array}{l}\text { Female, number (\%) } \\
\text { Male, number (\%) }\end{array}$ & $\begin{array}{l}16(50) \\
16(50)\end{array}$ & $\begin{array}{l}15(53.6) \\
13(46.4)\end{array}$ & $0.782^{*}$ \\
\hline $\begin{array}{l}\text { Hospitalization of newborn (+), number (\%) } \\
\text { Hospitalizasyon of newborn (-), number (\%) }\end{array}$ & $\begin{array}{l}5(15.6) \\
27(84.4)\end{array}$ & $\begin{array}{c}0(0.0) \\
28(100)\end{array}$ & $0.055^{*}$ \\
\hline Apgar score, 1 min & $6.35 \pm 1.30$ & $6.46 \pm 1.29$ & 0.735 \\
\hline Apgar score, 5 min & $8.09 \pm 1.44$ & $8.04 \pm 1.41$ & 0.941 \\
\hline Preterm newborn $(n, \%)$ & $7(21.8 \%)$ & $5(17.9 \%)$ & 0.476 \\
\hline $\begin{array}{l}\text { Breast Milk, number (\%) } \\
\text { BreastMilk + Formula, number (\%) } \\
\text { Formula, number (\%) }\end{array}$ & $\begin{array}{c}27(84.4) \\
4(12.5) \\
1(3.1)\end{array}$ & $\begin{array}{l}28(100) \\
0(0.0) \\
0(0.0)\end{array}$ & $0.116^{*}$ \\
\hline
\end{tabular}

a - Independent Sample T Test b: Mann Whitney U; * - Chi Square Analysis; $\mathrm{p}<0.05$ (statistically significant) Fisher's Exact is used in cases where the expected value assumption of Chi-square analysis is not provided; BMI — body mass Index; SD — standart deviation

were not affected, no iodine-containing agents were used before or during delivery, and care was also taken that no iodine preparations were used for cleaning the abdomen of the infant for the first 10 days.

In the current study, low UIC was determined in $33 \%$ of the mothers and normal UIE in $63.3 \%$ in the postoperative period. This could be attributed to the population not being from a region of ID or the dietary use of salt containing iodine. There was determined to be normal UIE in $90 \%$ of the newborns and they were seen to have sufficient iodine levels. To date, no studies have been conducted to determine whether neonatal iodine and thyroid hormone levels are affected by the timing of cord clamping. In the current study, there was observed to be no difference between the two groups in terms of maternal and neonatal UIC levels ( $p=0.379, p=0.495$, respectively).
It is known that permanent hypothyroidism can cause various disorders in newborns, such as low birthweight, retarded development and mental retardation [17]. Herbstmann et al. [18], reported that the thyroid hormone levels of newborns were extremely dynamic and could be affected by several biological and birth-related factors. Consistent with findings in literature, a statistically significant difference was determined between the groups in the FT3 and FT4 levels measured on the first day, and due to normal functioning of the thyroid gland, the FT3 and FT4 levels on the $10^{\text {th }}$ day were seen to have returned to normal in all the newborns, which again proved the dynamism of this process.

Kok et al. [19], reported that there could be a relationship between congenital hypothyroidism and low birthweight and low APGAR scores. However, to the best of our knowledge, the relationship between hypothyroidism and 


\begin{tabular}{|c|c|c|c|c|}
\hline \multicolumn{2}{|l|}{ Variables } & $\begin{array}{l}\text { Group } 1 \\
(n=32)\end{array}$ & $\begin{array}{l}\text { Group } 2 \\
(\mathrm{n}=28)\end{array}$ & $\mathbf{p}$ \\
\hline \multirow{2}{*}{$\begin{array}{l}\text { Maternal TSH level } \\
\text { range: } 0.27-4.2 \mathrm{mIU} / \mathrm{L}\end{array}$} & Normal & $29(90.6 \%)$ & $24(85.7 \%)$ & \multirow{2}{*}{0.423} \\
\hline & High & $3(9.4 \%)$ & $4(14.3 \%)$ & \\
\hline \multirow{2}{*}{$\begin{array}{l}\text { Neonatal TSH level Day } 0 \\
\text { range: } 0.7-15.2 \mathrm{mlU} / \mathrm{L}\end{array}$} & Normal & 31 (96.9\%) & $28(100 \%)$ & \multirow{2}{*}{0.533} \\
\hline & High & $1(3.1 \%)$ & $0(0 \%)$ & \\
\hline \multirow{2}{*}{$\begin{array}{l}\text { Neonatal TSH level Day } 10 \\
\text { range: } 0.7-15.2 \mathrm{mIU} / \mathrm{L}\end{array}$} & Normal & 32 (100\%) & $28(100 \%)$ & \multirow{2}{*}{ NA } \\
\hline & High & $0(0 \%)$ & $0(0 \%)$ & \\
\hline \multirow{2}{*}{$\begin{array}{l}\text { Maternal FT4 level } \\
\text { range: } 0.85-1.7 \mathrm{ng} / \mathrm{dL}\end{array}$} & Low & $6(18.8 \%)$ & $2(7.2 \%)$ & \multirow{2}{*}{0.175} \\
\hline & Normal & $26(81.2 \%)$ & $26(92.8 \%)$ & \\
\hline \multirow{2}{*}{$\begin{array}{l}\text { Neonatal FT4 level Day } 0 \\
\text { range: } 0.86-2.49 \mathrm{ng} / \mathrm{dL}\end{array}$} & Low & $5(15.6 \%)$ & $0(0 \%)$ & \multirow{2}{*}{0.037} \\
\hline & Normal & 27 (84.4\%) & $28(100 \%)$ & \\
\hline \multirow{2}{*}{$\begin{array}{l}\text { Neonatal FT4 level Day } 10 \\
\text { range: } 0.86-2.49 \mathrm{ng} / \mathrm{dL}\end{array}$} & Low & $0(0 \%)$ & $0(0 \%)$ & \multirow{2}{*}{ NA } \\
\hline & Normal & $32(100 \%)$ & 28 (100\%) & \\
\hline \multirow{2}{*}{$\begin{array}{l}\text { Maternal FT3 level } \\
\text { range: } 2.04-4.4 \mathrm{ng} / \mathrm{L}\end{array}$} & Low & $2(6.3 \%)$ & $1(3.6 \%)$ & \multirow{2}{*}{0.551} \\
\hline & Normal & 30 (93.7\%) & 27 (96.4\%) & \\
\hline \multirow{2}{*}{$\begin{array}{l}\text { Neonatal FT3 level Day } 0 \\
\text { range: } 1.73-6.3 \mathrm{ng} / \mathrm{L}\end{array}$} & Low & 20 (62.5\%) & $8(28.5 \%)$ & \multirow{2}{*}{0.009} \\
\hline & Normal & $12(37.5 \%)$ & $20(71.5 \%)$ & \\
\hline \multirow{2}{*}{$\begin{array}{l}\text { Neonatal FT3 level Day } 10 \\
\text { range: } 1.73-6.3 \mathrm{ng} / \mathrm{L}\end{array}$} & Low & $2(6.3 \%)$ & $2(7.2 \%)$ & \multirow{2}{*}{0.641} \\
\hline & Normal & 30 (93.7\%) & 26 (92.8\%) & \\
\hline
\end{tabular}

FT3 - serum concentrations of free triiodothyronine (ng/dL); FT4 - serum concentrations of free thyroxine (ng/dL); TSH — serum concentrations of thyroid-stimulating hormone (mlU/L); NA — not available

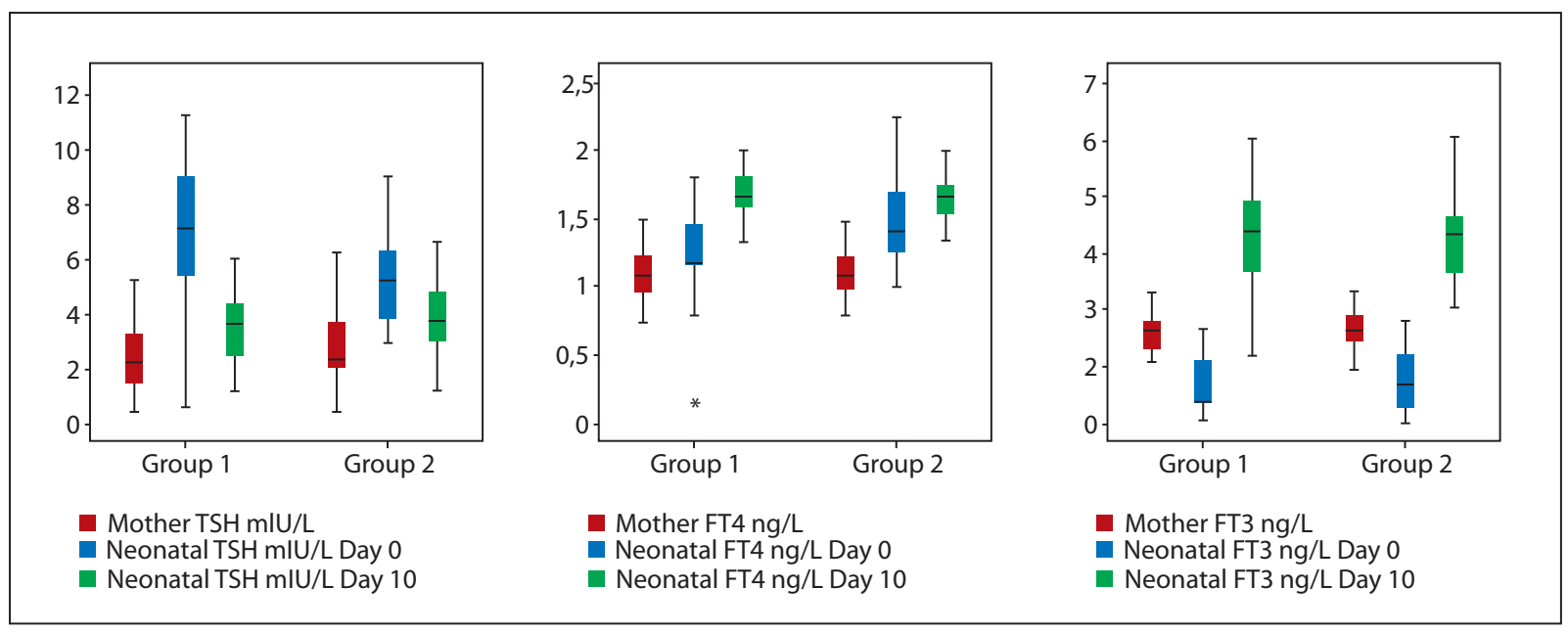

Figure 1. Maternal and neonatal thyroid hormone values

conditions such as APGAR scores and birthweight has not been previously evaluated in newborns with a normally functioning thyroid gland. This was evaluated in the current study, and there was seen to be no relationship between this condition in euthyroid infants and birthweight or APGAR scores, even if TSH levels were high or FT4 levels were low during the birth ( $r: 0.114, p=0.379)$.
However, as strict patient selection criteria were applied in this study, and the patients had reached term, it was considered that the relationship was not significant because of factors such as the high APGAR scores of the newborns. Further studies of a greater number of patients and preterm pregnancies would be able to provide more robust results. 


\begin{tabular}{|c|c|c|c|c|}
\hline Variables & & Group $1(n=32)$ & Group $2(n=28)$ & p \\
\hline \multirow{2}{*}{$\begin{array}{l}\text { Maternal vitamin B12 level } \\
\text { range: } 197-771 \mathrm{ng} / \mathrm{L}\end{array}$} & Low & 19 (59.3\%) & 11 (39.3\%) & \multirow{2}{*}{0.098} \\
\hline & Normal & $13(40.7 \%)$ & $17(60.7 \%)$ & \\
\hline \multirow{2}{*}{$\begin{array}{l}\text { Neonatal vitamin B12 level } \\
\text { range: } 197-771 \mathrm{ng} / \mathrm{L}\end{array}$} & Low & 20 (62.5\%) & $8(28.6 \%)$ & \multirow{2}{*}{0.009} \\
\hline & Normal & $12(37.5 \%)$ & $20(71.4 \%)$ & \\
\hline \multirow{3}{*}{$\begin{array}{l}\text { Maternal folic acid level } \\
\text { range: } 4.6-18.7 \mathrm{ng} / \mathrm{mL}\end{array}$} & Low & $5(15.6 \%)$ & $2(7.2 \%)$ & \multirow{3}{*}{0.567} \\
\hline & Normal & $22(68.2 \%)$ & $22(78.4 \%)$ & \\
\hline & High & $5(15.6 \%)$ & $4(14.4 \%)$ & \\
\hline \multirow{3}{*}{$\begin{array}{l}\text { Neonatal folic acid level } \\
\text { range: } 4.6-18.7 \mathrm{ng} / \mathrm{mL}\end{array}$} & Low & $0(0 \%)$ & $0(0 \%)$ & \multirow{3}{*}{0.032} \\
\hline & Normal & 19 (59.3\%) & $14(50 \%)$ & \\
\hline & High & $13(40.7 \%)$ & $14(50 \%)$ & \\
\hline \multicolumn{2}{|l|}{ Maternal UIC ${ }^{1}$} & $223.81 \pm 145.69$ & $275.11 \pm 180.51$ & \multirow{5}{*}{0.228} \\
\hline \multicolumn{2}{|l|}{$\mathrm{UIC}_{,}<100 \mu \mathrm{g} / \mathrm{L}^{2}$} & $11(34.4 \%)$ & $9(32.1 \%)$ & \\
\hline \multicolumn{2}{|l|}{ UIC, $100-150 \mu \mathrm{g} / \mathrm{L}^{2}$} & $8(25.0 \%)$ & $3(10.7 \%)$ & \\
\hline \multicolumn{2}{|l|}{ UIC, $151-249 \mu \mathrm{g} / \mathrm{L}^{2}$} & $6(18.8 \%)$ & $8(28.6 \%)$ & \\
\hline \multicolumn{2}{|l|}{$\mathrm{UIC}, \geq 250 \mu \mathrm{g} / \mathrm{L}^{2}$} & $7(21.8 \%)$ & $8(28.6 \%)$ & \\
\hline \multicolumn{2}{|l|}{ Neonatal UIC ${ }^{1}$} & $200.61 \pm 173.47$ & $239.34 \pm 199.96$ & \multirow{5}{*}{0.241} \\
\hline \multicolumn{2}{|l|}{$\mathrm{UIC}_{1}<100 \mu \mathrm{g} / \mathrm{L}^{2}$} & $1(3.1 \%)$ & $3(10.7 \%)$ & \\
\hline \multicolumn{2}{|l|}{ UIC, $100-150 \mu \mathrm{g} / \mathrm{L}^{2}$} & $7(21.8 \%)$ & $3(10.7 \%)$ & \\
\hline \multicolumn{2}{|l|}{ UIC, $151-249 \mu \mathrm{g} / \mathrm{L}^{2}$} & $18(56.3 \%)$ & $14(50.0 \%)$ & \\
\hline \multicolumn{2}{|l|}{$\mathrm{UIC}_{,} \geq 250 \mu \mathrm{g} / \mathrm{L}^{2}$} & $6(18.8 \%)$ & $8(28.6 \%)$ & \\
\hline
\end{tabular}

UIC - urinary iodine concentration ( $\mu \mathrm{g} / \mathrm{L}) ; \mathrm{p}$ - level of significance; ${ }^{1}$ Expressed as mean \pm standard deviation; ${ }^{2}$ Expressed as number $(\%) ; \mathrm{UIC},(<100 \mu \mathrm{\mu g} / \mathrm{L} 2) ;$ moderate and

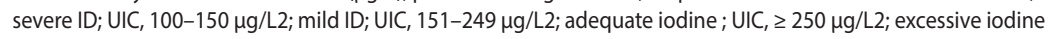

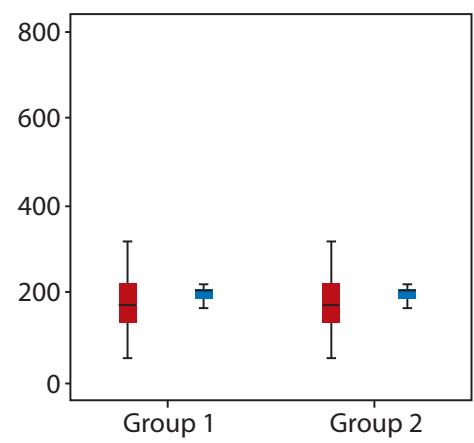

Maternal B12 ng/L Neoanatal B12 $\mathrm{ng} / \mathrm{L}$

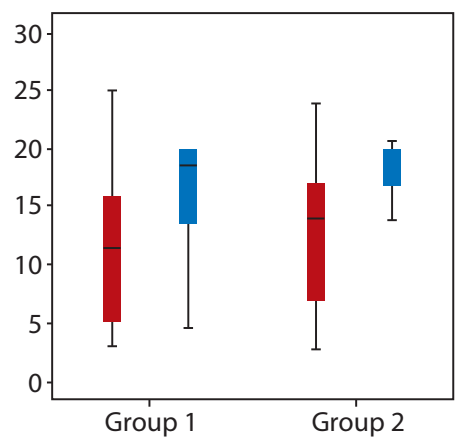

Maternal folic acid $\mathrm{ng} / \mathrm{mL}$ Neonatal folic acid $\mathrm{ng} / \mathrm{mL}$

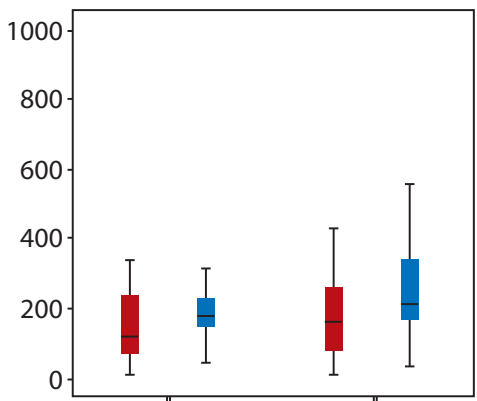

Group 1

Group 2

Maternal urine lodine $\mathrm{ng} / \mathrm{mL}$ Neonatal urine lodine $\mathrm{ng} / \mathrm{mL}$

Figure 2. Maternal and neonatal vitamin B12, folic acid and urinary iodine concentration values

There are few publications on important nutrients such as zinc and vitamin B complexes (B1, B2 and B3) that define macro and micro nutrition related to pregnancy outcomes [20]. Folate and vitamin B12 deficiencies may cause megaloblastic anemia [21].

It is predicted that B12 may affect implantation and fetal growth, and it is thought that B12 deficiency may affect more than three quarters of some pregnant populations. A small number of studies have been conducted to evaluate the possible effects of deficiency during pregnancy on birthweight and the duration of pregnancy. A recent meta-analysis concluded that multiple micronutrient supplements may reduce the risk of low birthweight and stillbirths, but not the birth or neonatal mortality rates [22]. 
It has been demonstrated that maternal vitamin B1 2 concentration affects vitamin B12 concentration in the foetal and neonatal period [22]. Previous cross-sectional studies conducted in Norway, Turkey, Germany, the United Kingdom, Serbia and Brazil have shown that there is a significant relationship between the vitamin B12 status of the mother and the infant [23, 24].

However, in a study conducted in Belgium, no significant relationship was found between the vitamin B12 concentrations of the mother and newborn [25]. When both groups were examined in the current study, the vitamin B12 level in the late cord clamping group was found to be higher than in the early cord clamping group $(p=0.009)$. The correlation analysis applied showed that there was a correlation between the maternal and neonatal vitamin B12 levels ( $r: 0.334, p=0.009$ ). These results were found to be consistent with the findings of previous studies in literature.

There has been determined to be an association between the folate level in pregnancy and reduced risk of pre-eclampsia, congenital heart disease and premature birth. Folic acid supplementation during pregnancy increases maternal serum and cord blood folate concentration [26].

Ahn et al. [27], showed that folate levels in umbilical cord blood were twice that of maternal serum and folate levels in the placenta were higher (average $998 \mathrm{ng} / \mathrm{g}$ ). The maternal folate concentration was found to be positively correlated with cord blood and placental tissue. Folate concentrations in cord blood vary depending on maternal age and maternal nutritional status. In women with low folate status, the level of folate in the fetus is still higher than in the maternal blood. This indicates that folate can accumulate in the placenta or umbilical cord from the maternal organism and then be carried to the fetus [27]. The results of other studies have shown that low folate status in pregnant women is determined by young maternal age, low education level and low annual income [28]. Since the age, gravida, parity, gestational age, BMI, weight gain during pregnancy and sociodemographic attributes were similar in both groups in the current study, folate and B12 levels were examined irrespective of these parameters.

In the current study, there was no difference between the groups in respect of the maternal folate levels $(p=0.567)$. In the early clamping group, folate levels above normal were determined in $15.6 \%$ of the mothers and in $40.7 \%$ of the newborns, while in the late clamping group, these rates were $14.4 \%$ and $50 \%$, respectively. These results were consistent with data in literature that neonatal folate levels could be higher than maternal folate levels.

The effect of clamping time, which was reported for the first time in literature in the current study, was found to have a positive effect on folate values ( $p=0.032$ ). This could be attributed to more folic acid accumulated in the placenta passing to the fetus, as stated in previous studies. However, this relationship was not seen with correlation analysis in the current study ( $r: 0.134, p=0.307)$. Further studies with a greater number of patients and longer clamping time may be able to determine a significant relationship.

Finally, in our study, groups were evaluated in terms of the newborns' needs for hospitalization. Of the total newborns included in the study, 12 were in the late preterm group; seven in Group 1 (7/32) and five in Group 2 (5/28). When the groups were compared in respect of late preterm newborns, there was seen to be no significant difference between the groups $(p=0.476)$. However, when the infants were evaluated in respect of the requirement for hospitalization, five of the preterm newborns in Group 1 were hospitalized, whereas none of the newborns in Group 2 required hospitalization. This suggested that the application of late clamping could reduce the need for hospitalization of newborns.

Although the number of patients was determined to be sufficient in the power analysis conducted before the study, it can be considered that a greater number of patients is necessary to determine significant results for folic acid levels. It is hoped that this study will be of guidance for further studies. As the study was conducted with normal, healthy term newborns and normal APGAR scores were expected for the newborns, it is thought that the effect on neonatal APGAR scores of the elevated thyroid hormone levels that emerged as a result of late clamping cannot be fully understood. Therefore, this study could be a pioneering study for further studies to be conducted on preterm and low birthweight newborns. Although the mode of delivery is a condition that could affect the hematological and biochemical parameters evaluated in the study, there was no significant difference between the patients in the two groups with normal delivery, so it can be considered that more accurate results can be provided with these types of studies made in homogenous groups.

\section{CONCLUSIONS}

The results of the current study clearly show that late clamping of the umbilical cord does not only influence hematological parameters. In addition to this effect, there could be a contribution to erythrocyte synthesis by allowing passage to the newborn of vitamins such as B12 and folic acid. Furthermore, as this study was conducted on newborns with high APGAR scores, although no beneficial effects were seen, there could be an increase in the rate of basal metabolism through an increase in thyroid hormone levels in the early neonatal period and it would seem possible that there are effects which could contribute to the early recovery of newborns. 


\section{Ethics committee approval}

The study was conducted in accordance with the principles stated in the Declaration of Helsinki.

\section{Sources of funding}

This research did not receive any specific grant from funding agencies in the public, commercial, or not-for-profit sectors.

\section{Financial disclosure}

The authors declare that this study has received no financial support.

\section{Conflict of interests}

The authors have no conflict of interests to declare.

\section{REFERENCES}

1. Mohammad K, Tailakh S, Fram K, et al. Effects of early umbilical cord clamping versus delayed clamping on maternal and neonatal outcomes: a Jordanian study. J Matern Fetal Neonatal Med. 2021; 34(2): 231-237, doi: 10.1080/14767058.2019.1602603, indexed in Pubmed: 30931665.

2. Airey RJ, Farrar D, Duley L. Alternative positions for the baby at birth before clamping the umbilical cord. J Matern Fetal Neonatal Med. 2014; 27(14): 1457-1461.

3. McDonald SJ. Physiology and management of the third stage of labour. In: Fraser D, Cooper M. ed. Myles Textbook for Midwives. Churchill Livingstone, Edinburgh 2003.

4. Wyllie J, Perlman JM, Kattwinkel J, et al. Neonatal Resuscitation Chapter Collaborators, Neonatal Resuscitation Chapter Collaborators, Neonatal Resuscitation Chapter Collaborators. Part 7: Neonatal Resuscitation: 2015 International Consensus on Cardiopulmonary Resuscitation and Emergency Cardiovascular Care Science With Treatment Recommendations (Reprint). Pediatrics. 2015; 136 Suppl 2(16 Suppl 1): S120-S166, doi: 10.1542/peds.2015-3373D, indexed in Pubmed: 26471381.

5. Bhatt $\mathrm{S}$, Alison BJ, Wallace EM, et al. Delaying cord clamping until ventilation onset improves cardiovascular function at birth in preterm lambs. J Physiol. 2013; 591(8): 2113-2126, doi: 10.1113/jphysiol.2012.250084, indexed in Pubmed: 23401615.

6. Brouwer E, Knol R, Vernooij ASN, et al. Physiological-based cord clamping in preterm infants using a new purpose-built resuscitation table: a feasibility study. Arch Dis Child Fetal Neonatal Ed. 2019; 104(4): F396-F402, doi: 10.1136/archdischild-2018-315483, indexed in Pubmed: 30282674.

7. Nagano N, Saito M, Sugiura T, et al. Benefits of umbilical cord milking versus delayed cord clamping on neonatal outcomes in preterm infants: A systematic review and meta-analysis. PLoS One. 2018; 13(8): e0201528, doi: 10.1371/journal.pone.0201528, indexed in Pubmed: 30161139

8. DeLong $\mathrm{G}$, Leslie $\mathrm{P}$, Wang $\mathrm{SH}$, et al. Effect on infant mortality of iodination of irrigation water in a severely iodine-deficient area of China. The Lancet. 1997; 350(9080): 771-773, doi: 10.1016/s0140-6736(96)12365-5.

9. Hollis BW, Wagner $\mathrm{CL}$, Wagner $\mathrm{CL}$, et al. Vitamin $\mathrm{D}$ administration during pregnancy as prevention for pregnancy, neonatal and postnatal complications. Rev Endocr Metab Disord. 2017; 18(3): 307-322, doi: 10.1007/s11154-017-9414-3, indexed in Pubmed: 28214921.

10. Lonnie M, Hooker E, Brunstrom JM, et al. Protein for Life: Review of Optimal Protein Intake, Sustainable Dietary Sources and the Effect on Appetite in Ageing Adults. Nutrients. 2018; 10(3), doi: 10.3390/nu10030360, indexed in Pubmed: 29547523

11. De-Regil LM, Peña-Rosas JP, Fernández-Gaxiola AC, et al. Effects and safety of periconceptional oral folate supplementation for preventing birth defects. Cochrane Database Syst Rev. 2015(12): CD007950, doi: 10.1002/14651858.CD007950.pub3, indexed in Pubmed: 26662928.

12. Barua S, Kuizon S, Junaid MA. Folic acid supplementation in pregnancy and implications in health and disease. J Biomed Sci. 2014; 21: 77, doi: 10.1186/s12929-014-0077-z, indexed in Pubmed: 25135350.

13. Askelöf $U$, Andersson $O$, Domellöf $M$, et al. Wait a minute? An observational cohort study comparing iron stores in healthy Swedish infants at 4 months of age after 10-, 60- and 180-second umbilical cord clamping BMJ Open. 2017; 7(12): e017215, doi: 10.1136/bmjopen-2017-017215, indexed in Pubmed: 29289934.

14. McDonald SJ, Middleton P, Dowswell T, et al. Effect of timing of umbilical cord clamping of term infants on maternal and neonatal outcomes. Evid Based Child Health. 2014; 9(2):303-397, doi: 10.1002/ebch.1971, indexed in Pubmed: 25404605.

15. Glinoer D. The importance of iodine nutrition during pregnancy. Public Health Nutr. 2007; 10(12A): 1542-1546, doi: 10.1017/S1368980007360886, indexed in Pubmed: 18053277.

16. Yaman AK, Demirel F, Ermiş B, et al. Maternal and neonatal urinary iodine status and its effect on neonatal TSH levels in a mildly iodine-deficient area. J Clin Res Pediatr Endocrinol. 2013; 5(2): 90-94, doi: 10.4274/Jcrpe.997, indexed in Pubmed: 23748060.

17. Kooistra L, Crawford S, van Baar AL, et al. Neonatal effects of maternal hypothyroxinemia during early pregnancy. Pediatrics. 2006; 117(1): 161-167, doi: 10.1542/peds.2005-0227, indexed in Pubmed: 16396874.

18. Herbstman J, Apelberg BJ, Witter FR, et al. Maternal, infant, and delivery factors associated with neonatal thyroid hormone status. Thyroid. 2008 18(1): 67-76, doi: 10.1089/thy.2007.0180, indexed in Pubmed: 18302520.

19. Kok JH, Hart G, Endert E, et al. Normal ranges of T4 screening values in low birthweight infants. Arch Dis Child. 1983; 58(3): 190-194, doi: 10.1136/adc.58.3.190, indexed in Pubmed: 6838250.

20. Lowensohn RI, Stadler DD, Naze C. Current Concepts of Maternal Nutrition. Obstet Gynecol Surv. 2016; 71(7): 413-426, doi: 10.1097/OGX.0000000000000329, indexed in Pubmed: 27436176.

21. WHO. Guideline: Optimal Serum and Red Blood Cell Folate Concentrations in Women of Reproductive Age for Prevention of Neural Tube Defects. World Health Organization, Geneva, Switzerland 2015.

22. Sukumar N, Rafnsson SB, Kandala NB, et al. Prevalence of vitamin B-12 insufficiency during pregnancy and its effect on offspring birth weight: a systematic review and meta-analysis. Am J Clin Nutr. 2016; 103(5): 1232-1251, doi: 10.3945/ajcn.115.123083, indexed in Pubmed: 27076577

23. Guerra-Shinohara EM, Paiva AA, Rondo PHC, et al. Relationship between total homocysteine and folate levels in pregnant women and their newborn babies according to maternal serum levels of vitamin B12. BJOG. 2002; 109(7): 784-791, doi: 10.1111/j.1471-0528.2002.01307.x, indexed in Pubmed: 12135215.

24. Koc A, Kocyigit A, Soran M, et al. High frequency of maternal vitamin B12 deficiency as an important cause of infantile vitamin B12 deficiency in Sanliurfa province of Turkey. Eur J Nutr. 2006; 45(5): 291-297, doi: 10.1007/s00394-006-0598-7, indexed in Pubmed: 16601915

25. Jacquemyn Y, Ajaji M, Karepouan N, et al. Vitamin B12 and folic acid status of term pregnant women and newborns in the Antwerp region, Belgium. Clin Exp Obstet Gynecol. 2014; 41(2): 141-143, indexed in Pubmed: 24779238.

26. Liu C, Liu C, Wang Q, et al. Supplementation of folic acid in pregnancy and the risk of preeclampsia and gestational hypertension: a meta-analysis. Arch Gynecol Obstet. 2018; 298(4): 697-704, doi: 10.1007/s00404018-4823-4, indexed in Pubmed: 29978414.

27. Ahn HS. Relation between folate levels of maternal-umbilical cord blood, placenta tissue and pregnancy outcomes. J Commun Nutrition. 2004; 6: 91-96.

28. Yila TA, Araki A, Sasaki S, Predictors of folate status among pregnant Japanese women: the Hokkaido Study on Environment and Children's Health, 2002-2012. Br J Nutr. 2016; 115(12): 2227-2235, doi: 10.1017/S0007114516001628, indexed in Pubmed: 27121118 